\title{
Understanding Of Nepalese Patients With Vitiligo About Their Disease
}

\author{
Agrawal $S^{1}$, Kumar $A^{2}$, Shyngwa $P M^{3}$ \\ ${ }^{I}$ Professor, Department of Dermatology \& \\ Venereology, B. P. Koirala Institute of Health \\ Sciences, Dharan, Nepal, \\ ${ }^{2}$ Senior Resident, ${ }^{3}$ Department of Psychiatry, \\ B. P. Koirala Institute of Health \\ Sciences, Dharan, Nepal
}

\section{Address for correspondence}

Dr. Sudha Agrawal

Prof \& Head, Department of Dermatology and Venereology

B. P. Koirala Institute of Health Sciences,

Dharan, Nepal

E-mail: sudha92@yahoo.com

\section{Citation}

Agrawal S, Kumar A, Shyngwa PM. Understanding of vitiligo patients about their condition. NJDVL 2014; 12(1): 7 - 13.

\begin{abstract}
Introduction: Vitiligo, a pigmentary disorder, may influence considerably patients' health-related quality of life (QoL) and psychological wellbeing. Previous reports indicated that the patients' illness understandings influence adherence behaviors and actions in various chronic dermatological conditions.

Objectives: To know the understanding of Nepalese patients with vitiligo about their disease by using illness perception questionnaire and also to investigate the potential factors that might influence it.
\end{abstract}

Material and Methods: The illness perception questionnaire consisting of 25 questions about causes, timeline, consequences and control of disease were given to 154 patients with vitiligo of 13 years or more age attending the dermatology OPD.

Results: A total of 146 patients completed the questionnaire. The belief about the causes of vitiligo was considered as "germs or virus" by $64.4 \%$ patients while half of the patients believed that vitiligo was due to "chance or fate". Vitiligo was considered to be a serious condition $(83.6 \%)$ and have had serious consequences on their life (63\%). Approximately half of the patients believed that their disease had serious economic and financial consequences more so in female patients and in those with generalized disease. Although $43.8 \%$ patients believed that their illness was likely to be permanent rather than temporary, $75 \%$ patients believed that vitiligo would improve with the time and their treatments were effective (75.3\%). However, females felt that there were very little that could be done to improve their vitiligo.

Conclusion: The knowledge about vitiligo is unsatisfactory and needs accessible, accurate, community based education about the natural history of vitiligo and the effectiveness of treatment.

Keywords: Illness perception questionnaire, Vitiligo

\section{Introduction}

Vitiligo is an autoimmune pigmentary disorder which runs an unpredictable course with an incidence of $0.1 \%$ to $8.8 \%{ }^{1}$ worldwide without any predilection for age or sex and familial inheritance is seen in $18 \%$ to $20 \%$ cases. $^{2}$ It is characterized by hypopigmented and depigmented macule due to loss of functioning of melanocytes. Various hypotheses have been proposed for the pathogenesis of vitiligo like genetic, biochemical/ 


\section{Original Article}

cytotoxic, neural and autoimmune. Not a single hypothesis is able to explain the aetiopathgenesis of vitiligo, therefore, convergence theory, which is a combination of multiple primary theories, is put forth. ${ }^{3}$

Vitiligo is not a life threatening condition and may influence considerably the patients' healthrelated quality of life (QoL) and psychological wellbeing. It has created a social stigma causing loss of the self esteem, social isolation, significant depression, ${ }^{4}$ difficulties in sexual relationships and perceived suitability for marriage. ${ }^{5,6}$ Previous reports indicated that the patients' illness understanding influences adherence, behaviours and actions in various chronic dermatological conditions. ${ }^{7-11}$ To our knowledge, there have been very few studies worldwide regarding vitiligo patients' beliefs about their condition. ${ }^{12,13}$ Moreover, there has been no such study performed in Nepalese vitiligo patients. Here, we bring about the present scenario of the understanding of the Nepalese population in the eastern part of Nepal with their disease; vitilgo. The aim of the study was to know the understanding of Nepalese patients with vitiligo about their disease by using illness perception questionnaire and also to investigate the potential factors that might influence it.

\section{Material and Methods}

A cross sectional study was done amongst 154 vitiligo patients attending the dermatology OPD in BPKIHS, Dharan, Nepal over a period of one year. All clinically diagnosed case of vitiligo patients of 13 years or above age were provided the Nepali version of Illness Perception Questionnaire (IPQ). As vitiligo is an asymptomatic disease, we did not use the "symptoms". The questionnaire consisted of 25 questions regarding the cause (10 items), consequences ( 6 items), timeline ( 3 items), and cure or control (6 items) of vitiligo. The answers were in the form of "agree" or "disagree". The IPQ has been previously used in patients with psoriasis. ${ }^{11}$ Other demographic details, such as age, sex, level of education, family history of vitiligo and duration of disease were also obtained from the patients to evaluate their influence on patients' beliefs.

Statistical analysis was conducted by means of SPSS statistical software for Windows (version 10.0, SPSS Inc, Chicago, IL, USA). Frequencies and percentages were used to summarize categorical responses and means, standard deviations, and ranges were used to summarize continuous responses. Pearson's Chi-squared test was used to determine the association between baseline variables and outcomes. Statistical significance was considered at $\mathrm{p}<0.05$.

\section{Results}

A total of 146 vitiligo patients completed the questionnaire and were included in the analysis. The clinico-demographic characteristics of the study population are depicted in Table 1 . The mean age of vitiligo patients was 32.05 years $(\mathrm{SD}=13.77$ years, $\mathrm{Range}=13-87$ years $)$ with the majority (32.9\%) between 21-30 years of age group. Amongst 146 patients, there were 80 $(54.8 \%)$ males and $66(45.2 \%)$ females. 
Vol. 12, No. 1, 2014

Original Article

Table 1: Characteristics of the study population

\begin{tabular}{|c|c|c|c|c|}
\hline \multicolumn{4}{|c|}{ Characteristics } & Study Population $(\mathrm{N}=146)$ \\
\hline \multicolumn{4}{|c|}{ Age in years $[$ Mean \pm SD (Range); Median] } & $32.05 \pm 13.77(13-87) ; 28.50$ \\
\hline \multirow{2}{*}{\multicolumn{3}{|c|}{$\operatorname{Sex}[n(\%)]$}} & Male & $80(54.8 \%)$ \\
\hline & & & Female & $66(45.2 \%)$ \\
\hline \multicolumn{4}{|c|}{ Age of onset in years [Mean \pm SD (Range); Median] } & $27.80 \pm 14.93(5-86) ; 24.00$ \\
\hline \multicolumn{4}{|c|}{ Duration of disease in months [Mean \pm SD (Range); Median] } & $51.04 \pm 56.94(1-360) ; 36.00$ \\
\hline \multirow{5}{*}{\multicolumn{3}{|c|}{ Occupation [n (\%)] }} & Unemployed & $38(26.0 \%)$ \\
\hline & & & Housewives & $45(30.8 \%)$ \\
\hline & & & Farmers & $33(22.6 \%)$ \\
\hline & & & Students & $29(19.9 \%)$ \\
\hline & & & Others & $1(0.7 \%)$ \\
\hline \multirow{4}{*}{\multicolumn{3}{|c|}{ Literacy $[\mathrm{n}(\%)]$}} & Illiterate & $26(17.8 \%)$ \\
\hline & & & $=$ Class 5 & $21(14.4 \%)$ \\
\hline & & & Class 6-12 & $81(55.5 \%)$ \\
\hline & & & Graduates & $18(12.3 \%)$ \\
\hline \multirow{5}{*}{$\begin{array}{l}\text { Precipitating factors } \\
\text { [n (\%)] }\end{array}$} & \multicolumn{2}{|l|}{ Absent } & & $118(80.8 \%)$ \\
\hline & \multirow{4}{*}{ Present } & \multirow{4}{*}{$\begin{array}{l}28 \\
(19.2 \%)\end{array}$} & Trauma & $16(57.1 \%)$ \\
\hline & & & Sun exposure & $13(46.4 \%)$ \\
\hline & & & Emotional stress & $4(14.3 \%)$ \\
\hline & & & Drugs & $3(10.7 \%)$ \\
\hline \multirow{2}{*}{\multicolumn{3}{|c|}{ Family history }} & Present & $12(8.2 \%)$ \\
\hline & & & Absent & $134(91.8 \%)$ \\
\hline \multirow{8}{*}{$\begin{array}{l}\text { Past treatment } \\
{[n(\%)]}\end{array}$} & No & & & $76(52.1 \%)$ \\
\hline & \multirow{7}{*}{ Yes } & \multirow{7}{*}{$\begin{array}{l}70 \\
(47.9 \%)\end{array}$} & Homeopathic or Ayurvedic & 28 \\
\hline & & & Topical steroids & 29 \\
\hline & & & Topical psoralens & 9 \\
\hline & & & Oral PUVA & 13 \\
\hline & & & Oral steroids & 6 \\
\hline & & & Oral immmunomodulators & 6 \\
\hline & & & Others & 26 \\
\hline \multirow{6}{*}{\multicolumn{3}{|c|}{ Site of involvement [n (\%)] }} & Upper extremities & $60(41.1 \%)$ \\
\hline & & & Lower extremities & $70(47.9 \%)$ \\
\hline & & & Trunk & $58(39.7 \%)$ \\
\hline & & & Face & $35(24.0 \%)$ \\
\hline & & & Neck & $31(21.2 \%)$ \\
\hline & & & Scalp & $25(17.1 \%)$ \\
\hline \multirow{3}{*}{\multicolumn{3}{|c|}{ Leukotrichia [n (\%)] }} & No & $102(69.9 \%)$ \\
\hline & & & Isolated & $27(18.5 \%)$ \\
\hline & & & With lesion & $17(11.6 \%)$ \\
\hline \multirow{5}{*}{\multicolumn{3}{|c|}{ Type of vitiligo [n (\%)] }} & Focal & $35(24.0 \%)$ \\
\hline & & & Acrofacial & $11(7.5 \%)$ \\
\hline & & & Segmental & $6(4.1 \%)$ \\
\hline & & & Vitiligo vulgaris & $77(52.7 \%)$ \\
\hline & & & Mucosal & $17(11.6 \%)$ \\
\hline \multirow{2}{*}{\multicolumn{3}{|c|}{ Course of disease }} & Stable & $55(37.6 \%)$ \\
\hline & & & Unstable & $91(62.3 \%)$ \\
\hline
\end{tabular}




\section{Original Article}

Approximately $70 \%$ patients had an education of secondary school or below, while 18 patients $(12.3 \%)$ had graduation or higher education and $26(17.8 \%)$ had no formal education. Majority of patients were housewives $(30.8 \%)$, farmers (22.6\%) and students (19.9\%), however 26\% patients were unemployed. Most of the patients (48.6\%) were the resident of Sunsari which indicates the easy accessibility to the hospital. Most of vitiligo patients were Hindu by religion i.e. $133(91.1 \%)$. A positive family history of vitiligo was noted in only $12(8.2 \%)$ patients. The mean age of onset of disease was 27.8 years $(\mathrm{SD}=14.93$ years, range 5-86 years) and the mean duration of the disease was 4.25 years $(\mathrm{SD}=4.74$ years, Range $=1$ month-10 years $)$. Precipitating factors for the disease were present in $28(19.2 \%)$ patients of which the most frequent was trauma in 16 patients.

Lower extremities $(47.9 \%)$ were the most common site of involvement followed by upper extremities (41.1\%) and trunk (39.7\%). Vitiligo vulgaris $(52.7 \%)$ and focal vitiligo $(24.0 \%)$ were the most frequent clinical presentation. Approximately fifty percent of patients had received treatment either topical or oral or both in the past.

\section{Beliefs about cause}

Table 2 depicts the percentage of patients "agreeing" with different cause items belief about vitiligo. Majority (64.4\%) of the individuals believed that vitiligo was due to "Germs or Virus" amongst them the illiteracy was significantly high $\left(80.9 \%\right.$ Vs $\left.19.1 \%, \chi^{2}=8.197, p=0.004\right)$. Fifty five percent Patients believed that vitiligo was due to "chance or fate". Patients who believed that vitiligo was a result of their poor medical care were more likely to have generalized vitiligo $\left(33 \%\right.$ Vs $\left.15.4 \%, \chi^{2}=5.294, p=0.021\right)$ and have longer duration of disease 5 years or more $(40.5 \%$ Vs $\left.22 \%, \chi^{2}=4.841, p=0.028\right)$. The other common beliefs regarding the causes of the disease were diet (24\%), their own behavior (22.6\%), stress $(22.6 \%)$ and pollution $(22.6 \%)$.
Table 2: Beliefs about cause of vitiligo

\begin{tabular}{lc}
\hline Belief & $\begin{array}{c}\text { No. (\%) of patients agreeing } \\
\text { or strongly agreeing with } \\
\text { each item (n=146) }\end{array}$ \\
\hline Germs or virus* & $95(64.4)$ \\
Chance or fate & $81(55.5)$ \\
Poor medical care ${ }^{@++}$ & $39(26.7)$ \\
Diet & $35(24.0)$ \\
My own behavior & $33(22.6)$ \\
Stress & $33(22.6)$ \\
Pollution & $33(22.6)$ \\
Other people & $26(17.8)$ \\
Genetic & $23(15.8)$ \\
My state of mind & $15(10.3)$ \\
\hline
\end{tabular}

*Illiterate; ${ }^{\circledR}$-generalized vitiligo; ${ }^{++}$Duration of disease 5 years or more $(<\mathrm{p}=0.05)$

\section{Beliefs about consequences}

Vitiligo was considered to be a serious condition $(83.6 \%)$ and have had serious consequences on their life (63\%). Approximately half of the patients believed that their disease had serious economic and financial consequences more so in female patients $\left(57.6 \%\right.$ Vs $\left.41.3 \%, \chi^{2}=3.858, \mathrm{P}=0.049\right)$ and generalized disease $\left(54.3 \%\right.$ Vs $38.5 \%, \chi^{2}=$ $3.343, p=0.048)$. Vitiligo had strongly affected the way patients see themselves as a person and the way others see them in $60.3 \%$ and $42.6 \%$ patients respectively and was found to be statistically significant in patients with generalized disease $\left(66 \%\right.$ Vs 50\%, $\chi^{2}=3.56, \mathrm{p}=0.044 ; 48.9 \%$ Vs $\left.30.8 \%, \chi^{2}=4.522, p=0.033\right)$. Table 3 shows the percentage of patients "agreeing" with each consequence item. 


\section{Original Article}

Table 3: Beliefs about the consequences of having vitiligo

\begin{tabular}{l|c}
\hline Belief & $\begin{array}{c}\text { No.(\%) of patients } \\
\text { agreeing or strongly } \\
\text { agreeing with each } \\
\text { item (n=146) }\end{array}$ \\
\hline $\begin{array}{l}\text { My vitiligo is a serious condition } \\
\text { My vitiligo has had a major } \\
\text { consequence on my life } \\
\begin{array}{l}\text { My vitiligo had strongly affected } \\
\text { the way I see myself as a person }\end{array}\end{array}$ & $122(83.6)$ \\
$\begin{array}{l}\text { My vitiligo has serious economic } \\
\text { and financial Consequences }\end{array}$ & $92(63.0)$ \\
$\begin{array}{l}\text { My vitiligo has strongly affected } \\
\text { the way others see me }{ }^{(}\end{array}$ & $71(48.6)$ \\
$\begin{array}{l}\text { My vitiligo has become easier to } \\
\text { live with }\end{array}$ & $62(42.5)$ \\
\hline \begin{tabular}{l} 
Generalized diseases; ${ }^{+}$Female $(\mathrm{p}<0.05)$ \\
\hline
\end{tabular}
\end{tabular}

\section{Beliefs about recurrence or chronicity}

The illness would be likely to be permanent rather than temporary believed by $43.8 \%$ patients (Table 4). This belief was significant in illiterate $(69.2 \%$ Vs $\left.30.8 \% \chi^{2}=8.286, p=0.004\right)$. Forty percent of patients believed whether their disease cleared it would always come back and was found to be statistically significant in patients with generalized disease $\left(46.8 \%\right.$ Vs $\left.26.9 \%, \chi^{2}=5.529, p=0.019\right)$ and having 5 years or more duration of disease $\left(54.1 \% \mathrm{Vs} 34.9 \%, \chi^{2}=4.249, \mathrm{p}=0.039\right)$.

Table 4: Beliefs on recurrence or chronicity of vitiligo

\begin{tabular}{lc}
\hline Belief & $\begin{array}{c}\text { No (\%) of patients } \\
\text { agreeing or strongly } \\
\text { agreeing with } \\
\text { each item (n=146) }\end{array}$ \\
\hline $\begin{array}{l}\text { My vitiligo will last for a long } \\
\text { time }\end{array}$ & $79(54.1)$ \\
$\begin{array}{l}\text { My vitiligo will last a short time } \\
\text { My vitiligo is likely to be } \\
\text { permanent rather than }\end{array}$ & $67(45.9)$ \\
$\begin{array}{l}\text { Temporary* } \\
\text { If my vitiligo clears it will always } \\
\text { come back }{ }^{@++}\end{array}$ & $64(43.8)$ \\
\hline
\end{tabular}

*Illiterate; ${ }^{\circledR}$ Generalized diseases: ${ }^{++}$Duration of disease 5 years or more $(\mathrm{p}<0.05)$

\section{Beliefs about cure and control}

Table 5 depicts the belief about cure or control of vitiligo. One hundred and fifteen $(78.8 \%)$ patients were optimistic of the course of disease that their vitiligo would improve with time and their treatments were effective $(75.3 \%)$ for those having disease duration less than 5 years $(62.2 \%$ Vs $\left.79.8 \%, \chi^{2}=4.634, p=0.031\right)$. On the other hand $70.5 \%$ patients believed that recovery from disease largely dependent on chance or fate and $60 \%$ of patients believed that their behavior could determine improvement or worsening of their illness. However, females felt that there were very little that could be done to improve their vitiligo $\left(72.7 \%\right.$ Vs $\left.56.3 \%, \chi^{2}=4.246, p=0.039\right)$.

Table 5: Beliefs about cure or control of vitiligo

\begin{tabular}{|c|c|}
\hline Belief & $\begin{array}{l}\text { No. }(\%) \text { of patients } \\
\text { agreeing or strongly } \\
\text { agreeing with } \\
\text { each item }(n=146)\end{array}$ \\
\hline $\begin{array}{l}\text { My vitiligo will improve with } \\
\text { time }\end{array}$ & $115(78.8)$ \\
\hline $\begin{array}{l}\text { There is a lot that I can do to } \\
\text { control my vitiligo }\end{array}$ & $111(76.0)$ \\
\hline $\begin{array}{l}\text { My treatment will be effective in } \\
\text { curing my vitiligo }\end{array}$ & $110(75.3)$ \\
\hline $\begin{array}{l}\text { Recovery from my vitiligo is } \\
\text { largely dependent on Chance or }\end{array}$ & \\
\hline fate & $103(70.5)$ \\
\hline $\begin{array}{l}\text { There is very little that can be } \\
\text { done to improve my vitiligo }{ }^{+}\end{array}$ & $93(63.7)$ \\
\hline $\begin{array}{l}\text { What I do can determine whether } \\
\text { my vitiligo gets better or worse }\end{array}$ & $88(60.3)$ \\
\hline
\end{tabular}

${ }^{++}$Duration of disease 5 years or more; ${ }^{+}$Female $(\mathrm{p}<0.05)$

\section{Discussion}

Vitiligo is a chronic autoimmune depigmenting disorder which runs a variable course. In eastern Nepal, vitiligo is still considered to have social stigma in the society. The results of our study showed, the disease was more common in males with the mean age of 32.08 years similar to the studies by Firooz et $\mathrm{al}^{12}$ and AlGhamdi. ${ }^{13}$ Seventy- 


\section{Original Article}

one $(48.6 \%)$ were resident of Sunsari which indicates the easy accessibility to the hospital. Twenty-six (17.8\%) patients were illiterate who contributed to the poor understanding of the disease. Precipitating factors, association of other disease and past treatment did not affect the study outcome.

Most of the patients, i.e. $64.4 \%$, believed that vitiligo was due to "Germs or Virus" and was more in the illiterate patients. Nepal having a high prevalence of leprosy, could account for this belief. However, Firooz et $\mathrm{al}^{12}$ found that majority $(62.5 \%)$ patients believed stress to be the cause of vitiligo. In another study, AlGhamdi ${ }^{13}$ reported fate to be the most common cause for the disease. Most of the patients $(83.6 \%)$ believed that it was a serious condition and $63 \%$ believed it had a major consequence on their life. Females predominantly believed that vitiligo had serious economic and financial consequences on their life. In the study by Firooz et al, 57.5\% patients agreed that vitiligo has strongly affected the way they see themselves, whereas $48.8 \%$ individuals had a major consequence in their life. ${ }^{12}$ Similarly, our patients believed that their illness had strongly affected the way they see themselves and the way others see them in $60.3 \%$ and $42.5 \%$ patients respectively.

Vitiligo can caused distress to the patients because of the expectation that it would last for a long time. ${ }^{13}$ Moreover in our study, some were afraid of its "permanent" course mainly in the illiterate patients, and that it "will always come back" and was more commonly observed in patients with generalized disease. Likewise in a study, onehalf of patients believed that illness was more likely to be permanent. However, these patients were more likely to have longer duration of disease and a higher level of education. ${ }^{12}$ In another study, $19 \%$ patients believed their disease to be long drawn. ${ }^{13}$

Many were optimistic about the course of disease that it will improve with time and could control their condition by various treatments. Similar belief of improvement of disease with time was seen among $57 \%$ patients in the study by AlGhamdi. ${ }^{13}$ However, in another study majority of patients believed their behavior to determine improvement or worsening of their disease. ${ }^{12}$ The strengths of this study are: (1) This is the first report about knowledge, beliefs and perceptions of vitiligo patients regarding their illness from Nepal and (2) The sample size is adequate in this type of studies done in vitiligo worldwide (146 patients). The limitation of this study is that the data are self-reported.

\section{Conclusion}

The knowledge about vitiligo is unsatisfactory and needs accessible, accurate, community based education about the natural history of vitiligo, its causes and the effectiveness of treatment. 


\section{Original Article}

\section{References}

1. Srivastava G. Vitiligo- introduction Asian Clinic Dermatol 1994; 1: 1-5.

2. Mason CP, Gawkrodger DJ. Vitiligo presentation in adults. Clin Exp Dermatol 2005; 30: 344-5.

3. Le Poole IC, Das PK, Van Den Wijngaard RM, Bos JD, Westerhof W. Review of ethiopathomechanism of vitiligo: a convergence theory. Exp Dermatol 1993; 2: 145-53.

4. Jemec GBE, Wulf HC. Patient-physician consensus on quality of life in dermatology. Clin Exp Dermatol 1996; 21: 177-9.

5. Halioua B, Beumont MG, Lunel F. Quality of life in dermatology. Int J Dermatol 2000; 39: 801-6.

6. Jayaprakasam A, Darvay A, Osborne G, McGibbon D. Comparison of assessments of severity and quality of life in cutaneous disease. Clin Exp Dermatol 2002; 27: 306-8.

7. Slevin ML, Plant H, Lynch D, Drinkwater J, Gregory WM. Who should measure quality of life, the doctor or the patient? Br J Cancer 1988; 57: 109-12.
8. Petrie K, Weinman J, Sharpe N, Buckley J. Role of patients' view of their illness in predicting return to work and functioning after myocardial infarction: longitudinal study. BMJ 1996; 312 : 1191-4.

9. Moss-Morris R, Petrie K, Weinman J. Functioning in chronic fatigue syndrome: do illness perceptions play a regulatory role? Br J Health Psychol 1996; 1: 15-25.

10. Weinman J, Petrie KJ, Moss-Morris R, Horne R. The illness perception questionnaire: a new method for assessing the cognitive representation of illness. Psychol Health 1996; 11: 114-29.

11. Fortune DG, Richards HL, Main CJ, Griffiths CE. What patients with psoriasis believe about their condition. J Am Acad Dermatol 1998; 39: 196-201.

12. Firooz A, Bouzari N, Fallah N, Ghazisaidi B, Firoozabadi MR, Dowlati Y. What patients with vitiligo believe about their condition? Int $\mathrm{J}$ Dermatol 2004; 43: $811-4$.

13. Alghamdi KM. Beliefs and perceptions of Arab vitiligo patients regarding their condition. Int $\mathrm{J}$ Dermatol 2010; 49: 1141-5. 